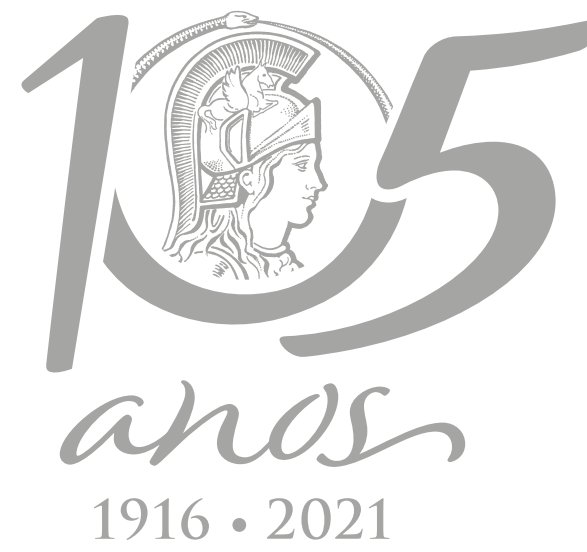

$1916 \cdot 2021$

\title{
Fatty acid profiles of the plasma and follicular fluid mares fed a combination of linseed and salmon oil
}

\author{
JESÚS A.S. VIAFARA, RICARDO V. PORTILHO, RENATA MACULAN, JOSÉ F. DE SOUZA \\ JÚNIOR, CAMILLA M. SILVA, PAULA G. RODRIGUES, MARCELO S. EL AZZI \& JOSÉ C. \\ DE SOUZA
}

\begin{abstract}
This study evaluated the presence of polyunsaturated fatty acids in circulating blood and in the ovarian follicular fluid of mares, after supplementation of the diet with linseed oil. Six Mangalarga Marchador mares, weighing $397.00 \pm 31.89 \mathrm{~kg}$, were kept on native pasture, and assigned to the current study. In a switch over design, mares were randomly allocated to receive $150 \mathrm{ml}$ of vegetable oil daily, containing polyunsaturated fatty acids n3 (62.23 g ALA, $20.34 \mathrm{~g}$ LA, $2.27 \mathrm{~g}$ EPA, $2.32 \mathrm{~g}$ DHA), ( $n=3$ ) or no supplementation $(n=3)$ in two replicates. Blood and follicular fluid samples were taken on the first day (D0) and every 30 days until the end of the supplementation period (D60). After 60 days of supplementation, mares were switched across the treatments. Plasma concentrations of linolenic acid in total fatty acids were higher $(P=0.006)$ in the supplemented compared to the control group $(1.89 \pm 0.13$ vs. $1.49 \pm 0.13 \%)$. There were positive correlations between plasma linoleic acid and follicular fluid arachidonic acid $\left(P=0.0106 ; r^{2}=0.13\right)$ and between plasma alpha linolenic acid and follicular fluid EPA $\left(P=0.0004 ; r^{2}=0.2544\right)$. Data indicated a low to moderate relationship between the dietary linseed-based oil supplementation studied and circulating and follicular fluid polyunsaturated fatty acids contents in mares.
\end{abstract}

Key words: DHA, equine, ovarian follicle, PUFA.

\section{INTRODUCTION}

A good nutritional balance must be applied in order to maintain adequate reproduction efficiency, especially for mares during the reproductive season (Soncin et al. 2009).

If nutrition is inadequate, often times, poor follicular development is found in mares which, as a consequence, do not ovulate normally or have deficient corpora lutea, leading, in turn, to early embryonic losses or underdeveloped fetuses (Shepherd et al. 2012). Studies have shown that diets rich in starch may result in decreased in the sensibility to insulin (insulin resistance), resulting in disruption of the hypothalmic-hypofhyseal ovariam axis compromising mare fertility (Jacobs et al. 2015).

In this sense, some studies have been carried out with supplementation of polyunsaturated fatty acids (PUFA) of breeding mares (Dinnetz et al. 2013, Jacobs et al. 2018), in order to improve reproduction.

Among PUFAs, the most important representatives are the fatty acids known as omega 3 (or n3) and omega 6 (or n6) (Vaz et al. 2014). Omegas 3 and 6 are found in large amounts in vegetable oils, most seeds and cereal grains, corn, soybean, sunflower and linseed oils (Martin et al. 2006). Equines respond quickly to dietary EPA supplementation, with a significant 
increase in blood concentration from as early as three days of supplementation (King et al. 2008).

The main metabolic functions of these compounds are related to the maintenance of endothelial cell integrity, prevention of atherosclerosis and cardiovascular changes; stimulation of insulin release; inhibition of vasoconstriction and platelet aggregation; participation in placental development, fetal growth and neuronal development, participation in immunomodulatory functions, release of cytokines and synthesis of eicosanoids (NRC 2007, King et al. 2008). The addition of LNA, an Omega 3 fatty acid also assists in the triggering of estrous cyclicity in prepubertal animals (Moreira et al. 2016). In cattle, the addition of linolenic acid (LNA), omega 3 ( $n-3)$ in the diet promotes a direct decrease in the secretion of PGF2 $\alpha$, due to the inhibition of the action of prostaglandin $\mathrm{H}$ synthase or, indirectly, by means of the products of this desaturation, eicosapentaenoic acid (EPA) and docosahexaenoic acid (DHA), which can improve the rate of pregnancy in the initial phase of gestation (Ambrose \& Kastelic 2003, Gregory et al. 2009).

In general, the role of PUFA metabolism in reproductive physiology is centered on the availability of substrates for estradiol synthesis in the follicles which is essential for normal follicular growth and ovulation (Wathes et al. 2007).

Considering the previous information, it is relevant to verify whether LNA, DHA, and EPA increase in the follicular fluid and plasma when mares are supplemented with linseed oil. The objective was to determine the concentrations of polyunsaturated fatty acids in the plasma and in the follicular fluid in mares supplemented with a linseed-based vegetable oil.

It was hypothesized that dietary 18:3n3 (omega 3) supplementation increases PUFA in the plasma and ovarian follicular fluid in mares, as a result of elongation and desaturation in the organism. A secondary hypothesis is that the concentrations of PUFAs in the plasma are correlated to those of the follicular fluid.

\section{MATERIALS AND METHODS}

This study is in accordance with the guidelines established by the Ethical Committee for the use of Animals in Research of the Federal University of Lavras (Protocol n 005/11).

\section{Animals, diets and experimental design}

Six Mangalarga Marchador mares of $7.95 \pm 6.4$ years old, weighing $397.00 \pm 31.89 \mathrm{~kg}$ and body scores ranging from 3.0 to 6.5 (1- emaciated to 9- excessively obese) (Henneke et al. 1983). Mares were kept during the dry season on native pastures in a continuous grazing system, and ad libitum access to water and mineral mix. All animals were previously dewormed and evaluated clinically and declared sound by an experienced veterinarian. Additionally, $2 \mathrm{Kg}$ of a concentrate ( $18 \%$ crude protein), were fed twice daily ( 7 a.m. and 3 p.m.). The concentrate included corn grain, soybean meal and wheat bran, containing an estimated $n 6: n 3$ ratio of 1.03:1.00 (Table I).

Mares were randomly allocated to one of two treatments: Treatment A ( $n=6)$ : unsupplemented regular diet; Treatment $B(n=6$ animals) $=$ Regular diet plus $150 \mathrm{~mL}$ of PUFA n3 oil. The oil was offered on top of the concentrate, divided into two $75 \mathrm{~mL}$ servings; one in the morning and the other in the afternoon feeding.

The linseed-based vegetable oil used contained poly-and mono-unsaturated fatty acids added of Canadian salmon oil. The fatty acid composition of the oil was determined by gas chromatography: $62.23 \mathrm{~g}$ of linolenic acid, $20.34 \mathrm{~g}$ of linoleic acid, $2.27 \mathrm{~g}$ of EPA and $2.32 \mathrm{~g}$ of 
Table I. Estimation of PUFA concentration in the experimental diet*, on dry matter (DM) basis.

\begin{tabular}{|c|c|c|c|c|c|c|c|}
\hline & \multicolumn{3}{|c|}{ Composition of feed } & \multicolumn{3}{c|}{ Quantity consumed (g/d) } \\
\hline Source & EE\% & $\begin{array}{c}\text { Ômega 6 } \\
\text { (\%) }\end{array}$ & $\begin{array}{c}\text { Ômega 3 } \\
\text { (\%) }\end{array}$ & $\begin{array}{c}\text { Intake } \\
\text { (Kg/DM/day) }\end{array}$ & $\begin{array}{c}\text { Intake } \\
\text { n6 }\end{array}$ & Intake n3 & $\begin{array}{c}\text { Relation } \\
\text { n6/n3 }\end{array}$ \\
\hline Corn grain & 4.20 & 49 & 0.5 & 1.10 & 22.63 & 0.23 & $98 / 1$ \\
\hline Soybean meal & 1.10 & 53.0 & 8.0 & 0.43 & 2.51 & 0.38 & $66 / 1$ \\
\hline Wheat bran & 4.3 & 0 & 0 & 0.18 & 3.07 & 0 & 0 \\
\hline Native pasture & 2.00 & 19.48 & 40.55 & 6.2 & 24.15 & 50.28 & $1 / 2.08$ \\
\hline Oil UFLA & -- & -- & -- & 20.34 & 62.23 & $1 / 3.06$ & 20.34 \\
\hline Total & 11.6 & 121.48 & 49.05 & 7.91 & 72.7 & 113.09 & $1 / 1.55$ \\
\hline
\end{tabular}

${ }^{*}$ Hypothetical estimate of preparation of grains in concentrated (18\% CP: $61 \%$ corn grain, $24 \%$ soybean meal, $10 \%$ wheat bran. ${ }^{1}$ Source: NRC (2007). ${ }^{2} \%$ BW of $400 \mathrm{~kg}$, concentrate $1.8 \mathrm{Kg}$, forage DM $6.2 \mathrm{Kg} .{ }^{3}$ Analized values by gas chromatographic.

DHA, considering that the density of the linseed oil was 0.9285 (Clark \& Tschentke 1929). The antinutritional factors were deactivated and the supplement enriched with vitamin E.

Before the beginning of each trial, mares went through a fourteen-day adaptation period, during which the oil amount was increased daily until the total intake proposed was reached (150 $\mathrm{mL}$ of the oil daily). In a crossover design, animals were switched across the treatments in two replicates. In the first replicate, three mares were randomly allocated to the PUFA group or Control group for sixty days. Mares were reversed across the treatments after a sixty-day interval, in order to remove the possible PUFA residual effects and for adaptation.

\section{Follicular fluid aspiration and blood sampling}

Before the beginning of the experiment, mares received an intra-muscular (IM) injection of $5 \mathrm{mg}$ of dinoprost tromethamine (Lutalyse ${ }^{\oplus}$ ). Mares were submitted to four follicular aspirations (largest follicles detected) at 30-days intervals, as described below:

Period 1: follicular aspirations 30 days before the initiation of the treatments; Period 2: follicular aspirations 30 days after initiation of the treatments; Period 3: follicular aspirations 60 days after initiation of the treatments.

A mild sedation and epidural anesthesia were given before follicular aspirations according to previously described procedures (Carnevale \& Ginther 1993). A minimum of $0.5 \mathrm{~mL}$ of follicular fluid was obtained from the largest follicle detected on either ovary.

The follicular aspiration was guided by a 5.0 MHz microconvex transducer (UST974-5) with an Aloka SSD 500V unit connected to an aspiration guide, and using an 18G needle and aspiration line and $50 \mathrm{~mL}$ centrifuge tubes connected to a vacuum pump adjusted for 150 $\mathrm{mmHg}$ (Mozzaquatro 2008). Once the procedure was finished, mares received an antibiotic and anti-inflammatory combination IM injection (1 $\mathrm{mL}$ per $25 \mathrm{~kg}$ of bodyweight, Pencivet ${ }^{\circledR}$ Plus).

The follicular fluid was immediately stored in sterile plastic tubes at $4^{\circ} \mathrm{C}$; later the fluid was centrifuged ( $1500 \times \mathrm{g}$ for ten minutes) and the supernatant collected and stored at $-20^{\circ} \mathrm{C}$ until analysis (Gastal et al. 2010).

Blood samples $(5 \mathrm{~mL}$ ) were obtained by jugular venipuncture in a closed system 
(Vaccutainer ${ }^{\circledR}$ ) containing EDTA in the same day as the follicular aspirations. Blood samples were centrifuged ( $1500 \times \mathrm{g}$ for ten minutes). Plasma was separated and stored at $-20^{\circ} \mathrm{C}$ (Soncin et al. 2009).

\section{Lipid extraction and profile determination}

Determination of the lipid profile was according to a previously described methodology (Folch et al. 1957). Once the original samples were prepared, $1 \mathrm{~mL}$ subsamples were used for the chromatography readings, which were done at the Animal Metabolism and Growth Laboratory of the University of São Paulo (USP) in PiracicabaSP- Brazil. A $1 \mu \mathrm{L}$ aliquot of the esterified extract was injected into the chromatography unit and the identification of the fatty acids done by comparison between the retention times and the percentage of the fatty acids present, performed with the Chromquest 4.1 software (Thermo Electron). The standard from Supelco TM Component FAME Mix, cat 18919 was used. It was used a column of gas chromatography of $100 \mathrm{~m}$.

\section{Statistical analyses}

All data were analyzed by the procedures of the SAS ${ }^{\oplus}$ package (Statistical Analysis System ${ }^{\circledR}$ 1998). The fixed effects of treatment, time and interactions on follicular fluid and plasma lipid concentrations were submitted to the Mixed procedure using the lowest Akaike criterium value as the covariance structure in each case. The effect of animal within treatment was the error term. Means were compared by orthogonal contrasts. The GLM procedure was used to obtain the means and the standard errors.

Variables were checked for residual normality (Univariate) and submitted to the Bartlett test to evaluate variance homogeneity. Data which did not meet analysis of variance criteria were transformed (base-10 logarithm; inverse $-1 / X$; or squared $-X^{* *}-2$ ). Variables that could not be adjusted to normality (nonparametric) after transformation were evaluated by the Wilcoxon test (NPAR1WAY) and submitted to the Genmod procedure considering the Poisson distribution and repeated options.

Statistical differences and tendencies were defined as probabilities of 5 and 15\%. Serum fatty acid concentrations were regressed onto those of the follicular fluid by the Reg procedure.

\section{RESULTS}

\section{Fatty acid profiles of follicular fluid}

Omega 3 and 6 supplementation increased the concentration of linolenic acid in the plasma $(P=0.006)$. Plasma LNA increased while mare were suplemmented between 30 and 60 days $(P=0.0001)$, however no interaction was observed between these variables (Table II).

The concentrations of linoleic acid LN tended to be lower $(\mathrm{P}=0.10)$ in period 1 compared to those of period 3 (Table III). The concentration of LNA in period 2 was higher $(P=0.05)$ compared to those of periods 1 and 3 (Table IV).

The concentrations of EPA in the follicular fluid tended $(P=0.11)$ to be lower in period 1 compared to that of period 2, but were similar to that of period 3 (Table IV). A greater $(P=0.06)$ concentration of DHA was found in the follicular fluid of controls mares compared to supplemented (Table IV).

The concentrations of the omega 3 fatty acid series were lower (EPA 0.07\% e DHA 0.03\%) than those of the omega 6 series (dihomogamalinolenic $0.16 \%$ and arachidonic acid $4.40 \%$ ) in the circulation (Tables II and III). Higher omega 6 fatty acid concentrations in the follicular fluid were also evident (Table V). 
Table II. Effect of linseed-based vegetable oil with addition of salmon oil Canada supplementation on the plasma concentrations of polyunsaturated Omega 3 fatty acid (\%) in Mangalarga Marchador mares.

\begin{tabular}{|c|c|c|c|c|c|c|c|c|}
\hline \multirow[b]{2}{*}{ FA } & \multirow[b]{2}{*}{ Treat } & \multicolumn{3}{|c|}{ Period" } & \multirow[b]{2}{*}{ Mean Treat } & \multicolumn{3}{|c|}{ Effect $P^{*}$} \\
\hline & & 1 & 2 & 3 & & $\mathbf{T}$ & $\mathbf{P}$ & TxP \\
\hline \multirow{3}{*}{$1^{\dagger}$} & Suppl. & $1.26 \pm 0.21$ & $1.84 \pm 0.24$ & $2.57 \pm 0.24$ & $1.89 \pm 0.13^{\mathrm{a}}$ & 0.006 & 0.0001 & 0.66 \\
\hline & Control & $1.03 \pm 0.19$ & $1.74 \pm 0.24$ & $1.67 \pm 0.24$ & $1.48 \pm 0.13^{b}$ & & & \\
\hline & Mean & $1.14 \pm 0.14^{a}$ & $1.79 \pm 0.17^{b}$ & $2.12 \pm 0.17^{b}$ & & & & \\
\hline \multirow{3}{*}{$2^{\ddagger}$} & Suppl. & $0.06 \pm 0.01$ & $0.10 \pm 0.02$ & $0.06 \pm 0.02$ & $0.07 \pm 0.01$ & 0.11 & 0.11 & 0.23 \\
\hline & Control & $0.03 \pm 0.01$ & $0.07 \pm 0.02$ & $0.05 \pm 0.02$ & $0.04 \pm 0.01$ & & & \\
\hline & Mean & $0.04 \pm 0.01^{A}$ & $0.08 \pm 0.01^{B}$ & $0.05 \pm 0.01^{A B}$ & & & & \\
\hline \multirow{3}{*}{$3^{\ddagger \dagger}$} & Suppl. & $0.04 \pm 0.02$ & $0.04 \pm 0.04$ & $0.01 \pm 0.05$ & $0.03 \pm 0.02$ & 0.92 & 0.49 & 0.38 \\
\hline & Control & $0.07 \pm 0.03$ & $-0.02 \pm 0.06$ & & & & & \\
\hline & Mean & $0.06 \pm 0.01$ & $0.01 \pm 0.03$ & & & & & \\
\hline
\end{tabular}

Distinct letter indicate differences $(P<0.05)$ and tendencies $(P<0.10)$. FA= Fatty Acid; $1^{\dagger}=C 18: 3 n 3$ (Linolenic Acid); $2^{\ddagger}=C 20: 5 n 3$ $(E P A) ; 3^{\ddagger t}=$ C22:6 n3 (DHA); "Period 1: follicular aspirations 30 days before the initiation of the treatments; Periods 2: follicular aspirations 30 days after the initiation of the treatment; Periods 3: follicular aspirations 60 days after initiation of the treatments. *Effect of P: T= Effect of treatment; P= Effect of period; TxP = interaction Treatment vs. Period.

Table III. Effect of linseed-based vegetable oil with addition of salmon oil Canada supplementation on the plasma concentrations of polyunsaturated Omega 6 fatty acid (\%) in Mangalarga Marchador mares.

\begin{tabular}{|c|c|c|c|c|c|c|c|c|}
\hline \multirow[b]{2}{*}{ FA } & \multirow[b]{2}{*}{ Treat } & \multicolumn{3}{|c|}{ Period ${ }^{\Uparrow}$} & \multirow[b]{2}{*}{ Mean Treat } & \multicolumn{3}{|c|}{ Effect P* } \\
\hline & & 1 & 2 & 3 & & $\mathbf{T}$ & $\mathbf{P}$ & TxP \\
\hline \multirow{3}{*}{$1^{\dagger}$} & Suppl. & $14.40 \pm 2.30$ & $19.75 \pm 2.7$ & $25.73 \pm 2.7$ & $19.1 \pm 1.5$ & 0.17 & 0.10 & 0.58 \\
\hline & Control & $15.56 \pm 2.26$ & $24.84 \pm 2.8$ & $28.60 \pm 2.8$ & $23.0 \pm 1.5$ & & & \\
\hline & Mean & $14.10 \pm 1.60^{\mathrm{A}}$ & $22.30 \pm 1.9^{\mathrm{AB}}$ & $27.17 \pm 1.9^{B}$ & & & & \\
\hline \multirow{3}{*}{$2^{\ddagger}$} & Suppl. & $0.16 \pm 0.03$ & $0.13 \pm 0.03$ & $0.20 \pm 0.03$ & $0.16 \pm 0.02$ & 0.21 & 0.87 & 0.15 \\
\hline & Control & $0.11 \pm 0.02$ & $0.13 \pm 0.03$ & $0.09 \pm 0.03$ & $0.11 \pm 0.02$ & & & \\
\hline & Mean & $0.13 \pm 0.02$ & $0.13 \pm 0.02$ & $0.14 \pm 0.02$ & & & & \\
\hline \multirow{3}{*}{$3^{\ddagger \dagger}$} & Suppl. & $4.26 \pm 0.70$ & $3.76 \pm 0.80$ & $5.13 \pm 0.80$ & $4.40 \pm 0.44$ & & & \\
\hline & Control & $4.49 \pm 0.64$ & $4.40 \pm 0.80$ & $4.53 \pm 0.80$ & $4.50 \pm 0.43$ & & & \\
\hline & Mean & $4.38 \pm 0.46$ & $4.08 \pm 0.55$ & $4.83 \pm 0.55$ & & & & \\
\hline
\end{tabular}

Distinct letter indicate differences $(P<0.05)$ and tendencies $(P<0.10)$. FA= Fatty Acid; $1 \dagger=C 18: 2 \mathrm{n} 6$ (Linoleic Acid); $2 \neq=C 20: 3 n 6$ (dihomo-gama linolenic); 3\$†=C20:4n6 (Arachidonic Acid). "Period 1: follicular aspirations 30 days before the initiation of the treatments; Periods 2: follicular aspirations 30 days after the initiation of the treatment; Periods 3: follicular aspirations 60 days after initiation of the treatment. *Effect of P: T= Effect of treatment; P= Effect of period; TxP = interaction Treatment vs. Period. 
Table IV. Effect of linseed-based vegetable with addition of salmon oil Canada supplementation on the follicular fluid concentrations of polyunsaturated Omega 3 fatty acid (\%) in Mangalarga Marchador mares.

\begin{tabular}{|c|c|c|c|c|c|c|c|c|}
\hline \multirow[b]{2}{*}{ FA } & \multirow[b]{2}{*}{ Treat } & \multicolumn{3}{|c|}{ Period } & \multirow[b]{2}{*}{ Mean Treat } & \multicolumn{3}{|c|}{ Effect $P^{*}$} \\
\hline & & 1 & 2 & 3 & & $\mathbf{T}$ & $\mathbf{P}$ & TxP \\
\hline \multirow{2}{*}{$1^{\dagger}$} & Suppl. & $0.32 \pm 0.10$ & $0.80 \pm 0.12$ & $0.31 \pm 0.12$ & $0.47 \pm 0.07$ & 0.48 & 0.05 & 0.43 \\
\hline & Control & $0.44 \pm 0.10$ & $0.49 \pm 0.12$ & $0.28 \pm 0.12$ & $0.40 \pm 0.07$ & & & \\
\hline & Mean & $0.38 \pm 0.07^{\mathrm{a}}$ & $0.63 \pm 0.09^{b}$ & $0.30 \pm 0.09^{a}$ & & & & \\
\hline \multirow{2}{*}{$2^{\ddagger}$} & Suppl. & $0.08 \pm 0.03$ & $0.08 \pm 0.04$ & $0.07 \pm 0.04$ & $0.08 \pm 0.02$ & 0.11 & 0.08 & 0.74 \\
\hline & Control & $0.06 \pm 0.04$ & $0.26 \pm 0.04$ & $0.19 \pm 0.04$ & $0.16 \pm 0.02$ & & & \\
\hline & Mean & $0.07 \pm 0.02^{A}$ & $0.17 \pm 0.03^{B}$ & $0.13 \pm 0.03^{\mathrm{AB}}$ & & & & \\
\hline \multirow{3}{*}{$3^{\ddagger \dagger}$} & Suppl. & $0.01 \pm 0.01$ & $0.00 \pm 0.01$ & $0.01 \pm 0.01$ & $0.01 \pm 0.00^{A}$ & 0.06 & 0.49 & 0.92 \\
\hline & Control & $0.02 \pm 0.01$ & $0.07 \pm 0.02$ & $0.03 \pm 0.01$ & $0.04 \pm 0.00^{B}$ & & & \\
\hline & Mean & $0.02 \pm 0.00$ & $0.04 \pm 0.01$ & $0.03 \pm 0.01$ & & & & \\
\hline
\end{tabular}

Distinct letter indicate differences $(P<0.05)$ and tendencies $(P<0.10)$. FA= Fatty Acid; 1†= C18:3n3 (Linolenic Acid); $2 \neq=C 20: 5 n 3$ (EPA); 3キt= C22:6 n3 (DHA). "Period 1: follicular aspirations 30 days before the initiation of the treatments; Periods 2: follicular aspirations 30 days after the initiation of the treatment; Periods 3: follicular aspirations 60 days after initiation of the treatments. *Effect of P: T= Effect of treatment; P= Effect of period; TxP = interaction Treatment vs. Period.

\section{Fatty acid profiles in blood plasma}

There was a positive correlation ( $P=0.0140$; $r^{2}=0.2677$ ) between plasma LNA and follicular fluid EPA concentrations. Similarly, there was a positive correlation $\left(P=0.0238 ; r^{2}=0.2113\right)$ between plasma LN and arachidonic acid concentrations in the follicular fluid.

\section{DISCUSSION}

The amount of fatty acids present in the oils fed influences their plasma concentrations. It has been shown that EPA and DHA were only found in appreciable amounts in the plasma of horses supplemented with oils that contained these fatty acids, e.g., fish-based oils (Vineyard et al. 2009). Thus, the lower concentrations of EPA and DHA observed

In the plasma of the supplemented group (Table II) in comparison to an experiment (King et al. 2008), in which higher doses of 10, 20 e 40 $\mathrm{g} /$ day of EPA (17.81 g) and DHA (21.32 g) containing oil sources were used. In the current study low fatty acid concentrations were seen.

The relatively low concentrations of EPA and DHA in the plasma of mares supplemented with linseed oil (63.23g of LNA) indicate that the conversion rate of PUFA's is limited in equines, in the present experiment. Compatible results were into the tissues, rather than remain in circulating plasma.

In humans, the bioconversion rate from LNA to EPA is lower than $10 \%$ and to DHA is below 0.10\% (Willians \& Burdge 2006).

Vegetable oil rich in Omega 3 was offered to the animals, expecting its bioconversion into its derivatives (EPA and DHA). According to one previous report (Pawlosky et al. 2001), only $0.2 \%$ of the linolenic acid was used for the biosynthesis of EPA in human plasma. The best biosynthetic pathway for very long chain fatty acids is from EPA, so that supplementing with this fatty acid is a better alternative to obtain DHA and that the 
Table V. Effect of linseed-based vegetable with addition of salmon oil Canada supplementation on the follicular fluid concentrations of polyunsaturated Omega 6 fatty acid (\%) in Mangalarga Marchador mares.

\begin{tabular}{|c|c|c|c|c|c|c|c|c|}
\hline \multirow[b]{2}{*}{ FA } & \multirow[b]{2}{*}{ Treat } & \multicolumn{3}{|c|}{ Period" } & \multirow[b]{2}{*}{ Mean Treat } & \multicolumn{3}{|c|}{ Effect P* } \\
\hline & & 1 & 2 & 3 & & $\mathbf{T}$ & $\mathbf{P}$ & TxP \\
\hline \multirow{3}{*}{$1^{\dagger}$} & Suppl. & $5.75 \pm 3.33$ & 12.874 .09 & $14.21 \pm 4.09$ & $10.9 \pm 2.23$ & 0.74 & 0.31 & 0.75 \\
\hline & Control & $7.55 \pm 3.34$ & $9.01 \pm 4.08$ & $6.27 \pm 4.08$ & $7.61 \pm 2.22$ & & & \\
\hline & Mean & $6.65 \pm 2.36$ & $10.94 \pm 2.90$ & $10.24 \pm 2.90$ & & & & \\
\hline \multirow{3}{*}{$2^{\ddagger}$} & Suppl. & $0.07 \pm 0.02$ & $0.11 \pm 0.02$ & $0.07 \pm 0.03$ & $0.08 \pm 0.01$ & 0.71 & 0.43 & 0.72 \\
\hline & Control & $0.10 \pm 0.02$ & $0.09 \pm 0.03$ & $0.07 \pm 0.03$ & $0.09 \pm 0.02$ & & & \\
\hline & Mean & $0.09 \pm 0.01$ & $0.10 \pm 0.02$ & $0.07 \pm 0.02$ & & & & \\
\hline \multirow{3}{*}{$3^{\neq \dagger}$} & Suppl. & $6.39 \pm 1.41$ & $6.11 \pm 1.72$ & $10.41 \pm 1.72$ & $7.64 \pm 0.94$ & 0.94 & 0.95 & 0.92 \\
\hline & Control & $7.13 \pm 1.41$ & $8.16 \pm 1.72$ & $9.18 \pm 1.72$ & $8.16 \pm 0.93$ & & & \\
\hline & Mean & $6.76 \pm 1.00$ & $7.14 \pm 1.22$ & $9.80 \pm 1.22$ & & & & \\
\hline
\end{tabular}

Distinct letter indicate differences $(P<0.05)$ and tendencies $(P<0.10)$. FA= Fatty Acid; 1† = C18:2 n6 (Linoleic Acid); $2 \neq=C 20: 3 n 6$ (dihomo-gama linolênic); 3\$†= C20:4n6 (Arachidonic Acid). "Period 1: follicular aspirations 30 days before the initiation of the treatments; Periods 2: follicular aspirations 30 days after the initiation of the treatment; Periods 3: follicular aspirations 60 days after initiation of the treatments. *Effect of P: T= Effect of treatment; P= Effect of period; TxP = interaction Treatment vs. Period.

utilization of linolenic acid may not be the best option (Pawlosky et al. 2001).

Therefore, it is concluded that the Omega 3 amount offered was minimally used for its main purpose (very long chain fatty acid synthesis), which was demonstrated by the Iow DHA concentrations in the plasma.

Alfa linolenic (LNA) acid may be metabolized by elongation and dessaturation to EPA, DPA and DHA. The eicosapentaenoic acid (DPA, 22:5n3) is formed by the elongation of the EPA chain and this conversion occurs in various steps. Firstly, the elongation of EPA to DPA (22:5n3) takes place, followed by the dessaturation of the tetracosapenthaenoic acid (24:5n3) to tetracosahexaenoic (24:6n3) and finally the oxidation to DHA (22:6 n3) in the peroxisome (Kaur et al. 2011).

The high LNA percentage (45.1\%) offered as a supplement may explain the low DHA concentrations observed in the plasma of linseed oil-supplemented animals.
The highest concentration of DHA in the control group could be due to a residual effect from the first replicate. The interval for the exchange of groups into the treatments may have been insufficient to reduce the follicular fluid PUFA concentration (Table IV).

Linoleic acid uses $\Delta 6$ dessaturase for its bioconversion into its metabolites, similarly to the $\alpha$-linolenic acid. Thus, they compete for this enzyme, resulting in greater concentrations of omega 6 fatty acids. Moreover, the $\Delta 6$ dessaturase have greater affinity for the omega- 6 series fatty acids and this cause a restriction depending on the omega- 6 diet content. Jacobs et al. (2018) supplemented pregnant mares with a marine source and observed greater DHA/EPA endometrial-tissue incorporation.

In the present study the highest concentrations of omega- 6 fatty acids (dihomogamalinolenic $0.16 \%$ and arachidonic acid $4.40 \%$ ) relative to omega-3 fatty acids (EPA and $\mathrm{DHA} 0.07 \%$ and $0.03 \%$, respectively) in the 
circulation (Tables II and III) suggests that a greater bioconversion of the series 6 into series 3 fatty acid may have occurred.

The positive correlations between plasma linolenic acid and follicular fluid EPA and between linoleic and arachidonic acid concentrations in the follicular fluid indicate the possible conversion of the former fatty acid in these two later very long chain derivatives. These correlations establish an important link between nutrition and reproductive function.

With longer supplementation periods, it would be expected that greater elongation rates and dessaturation of this fatty acid would occur, which could be benefic to equine reproduction.

There were no effects of treatment, period or interaction on the other PUFA plasma or follicular fluid concentrations analyzed (Tables II to $\mathrm{V}$ ).

The dietary supplementation with linseed oil enriched with $63.23 \mathrm{~g}$ of $\alpha$-linolenic acid, $20.34 \mathrm{~g}$ of linoleic acid, $2.27 \mathrm{~g}$ of EPA and $2.32 \mathrm{~g}$ of DHA influenced their concentrations in the plasma of supplemented mares however did not influence the n3 PUFA concentrations in the follicular fluid. This demonstrates that there is low conversion in the horse organism. Thus, it is necessary to provide nutritional sources with higher concentrations of EPA and DHA for a period exceeding 30 days in order to use PUFAs as a reproductive nutraceutical in mares.

\section{Acknowledgments}

The Brazilian Breeder's Association of Mangalarga Marchador Horse (ABCCMM) support and for graciously providing the stallions; This study was financed in part by the Coordenação de Aperfeiçoamento de Pessoal de Nivel Superior (CAPES), Brazil - Finance Code 001, and the Conselho Nacional de Desenvolvimento Científico e Tecnológico (CNPq), Brazil, for the scholarship provided.

\section{REFERENCES}

AMBROSE DJ \& KASTELIC JP. 2003. Dietary fatty acids in dairy cow fertility. Adv Dairy Technol 15: 35-47.
CARNEVALE EM \& GINTHER OJ. 1993. Use of a linear ultrasonic transducer for the transvaginal aspiration and transfer of oocytes in the mare. Equine Vet J 13: 331-333.

CLARK GL \& TSCHENTKE HL. 1929. Physico-chemical studies on the mechanism of the drying of linseed oil'l-changes in density of films. Ind Eng Chem Res 21: 621-627.

DINNETZ JM, FURTNEY SR, PENDERGRAFT IS, DAVIS EG, EPP TS \& MINTON JE. 2013. Omega-3 fatty acid supplementation reduces basal TNFa but not toll-like receptor-stimulated TNFa in full-sized and miniature mares. J Equine Vet Sci 33: 523-529.

FOLCH J, LEES M \& STANLEY GHS. 1957. A simple method for the isolation and purification of total lipides from animal tissues. J Biol Chem 226: 497-509.

GASTAL MO, GASTAL EL, BEG MA \& GINTHER OJ. 2010. Shortterm feed restriction decreases the systemic and intrafollicular concentrations of leptin and increases the vascularity of the preovulatory follicle in mares. Theriogenology 73: 1202-1209.

GREGORY RM, CARDONA JCA, OSPINA HP, RAMIREZ MH, MATTOS RC \& JOBIM MIM. 2009. Ácidos graxos poliinsaturados e seus efeitos no desempenho reprodutivo da vaca. Rev Bras Reprod Anim (Supl 6): 153-156.

HENNEKE DR, POTTER GD, KRIEDER JL \& YEATS BF. 1983. Relationship between body condition score, physical measurements and body fat percentage in mares. Equine Vet J 15: 371-372.

JACOBS RD, EALY A, PENNINGTON PM, PUKAZHENTHI B, WARREN L, WAGNER AL, JOHNSON KA, HESS TM, KNIGHT JW \& SPLAN RK. 2015. Effect of dietary omega-3 supplementation on equine endometrial and embryonic gene expression. J Equine Vet Sci 35(5): 438-439.

JACOBS RD, EALY A, PENNINGTON PM, PUKAZHENTHI, B, WARREN L, WAGNER AL, JOHNSON KA, HESS TM, KNIGHT JW \& SPLAN RK. 2018. Dietary supplementation of algae-derived omega-3 fatty acids influences endometrial and conceptus transcript profiles in mares. J Equine Vet Sci 62: 66-75.

KAUR G, CAMERON-SMITH D, GARG M \& SINCLAIR A. 2011. Docosapentaenoic acid (22:5n-3): A review of its biological effects. Prog Lipid Res 50: 28-34.

KING SS, ABUGHAZALEH AA, WEBEL SK \& JONES KL. 2008. Circulating fatty acid profiles in response to three levels of dietary omega-3 fatty acid supplementation in horses. J Anim Sci 86: 1114-1123.

MARTIN CA, ALMEIDA VV, RUIZ MR, VISENTAINER JEL, MATSHUSHITA M, SOUZA NE \& VISENTAINER JV. 2006. Ácidos graxos poliinsaturados ômega-3 e ômega-6: importância e ocorrência em alimentos. Rev Nutr 19: 761-770.

MOREIRA F, CHEUICHE ZMG, RIZZOTO G, SANTOS MQ, SCHUCH MS, FLACH MJ, GASPERIN BG, BIANCHI I \& LUCIA T. 2016. Metabolic and reproductive parameters in prepubertal gilts after 
omega-3 supplementation in the diet. Anim Reprod Sci 170: 178-183.

MOZZAQUATRO FD. 2008. Aspiração folicular na égua para indução da função lútea. Santa Maria: UFSM, 36 p. Tese (Doutorado). Programa de Pós-Graduação em Medicina Veterinária, Centro de Ciência Rurais, Universidade Federal de Santa Maria, Santa Maria, RS.

NRC - NATIONAL RESEARCH COUNCIL. 2007. Nutrient requirements of horses. National Academy Press, $6^{\text {th }}$ ed., Washington, DC.

PAWLOSKY RJ, HIBBELN JR, NOVOTNY JA \& SALEM NJ. 2001. Physiological compartmental analysis of a-linolenic acid metabolism in adult humans. J Lipid Res 42: 1257-1265.

SAS - STATISTICAL ANALYSIS SYSTEM. 1998. Version 9.0, SAS Institute, Inc. Cary, NC.

SHEPHERD ML, PLEASANT RS, CRISMAN MV, WERE SR, MILTON SC JR \& SWECKER WS. 2012. Effects of high and moderate non-structural carbohydrate hay on isulin, glucose, triglyceride, and leptin concentrations in overweight Arabian geldings. J Anim Physiol Anim Nutr 96: 428-435.

SONCIN MRSP, FURTADO CE, SILVA AA, RIGOLON LP, CAVALIERI FLB \& MORAES GV. 2009. Digestibilidade aparente, crescimento folicular e concentração de metabólitos sanguíneos de éguas recebendo concentrado com semente de linhaça integral (Linum usitatissimum L.). Acta Sci 31: 191-197.

VAZ DSS, GUERRA FMRM, GOMES CF, SIMÃO ANC \& JÚNIOR MARTINS J. 2014. A importância do ômega - 3 para a saúde Humana: um estudo de revisão. Rev Uningá 20: 48-54.

VINEYARD KR, WARREN LK \& KIVIPELTO J. 2009. Effect of dietary omega-3 fatty acid source on plasma and red blood cell membrane composition and immune function in yearling horses. Anim Sci 88: 248-257.

WATHES DC, ROBERT D, ABAYASEKARA E \& AITKEN A. 2007. Polyunsaturated fatty acids in male and female reproduction. Biol Reprod 77: 190-201.

WILLIAMS CM \& BURDGE G. 2006. Long-chain n-3 PUFA: Plant v. marine sources. Proc Nutr Soc 65: 42-50.

\section{How to cite}

VIAFARA JAS, PORTILHO RV, MACULAN R, SOUZA JÚNIOR JF, SILVA CM, RODRIGUES PG, EL AZZI MS \& SOUZA JC. 2021. Fatty acid profiles of the plasma and follicular fluid mares fed a combination of linseed and salmon oil. An Acad Bras Cienc 93: e20190443. DOI 10.1590/00013765202120190443.

Manuscript received on April 19, 2019; accepted for publication on October 21, 2019

\section{JESÚS A.S. VIAFARA ${ }^{1}$}

https://orcid.org/0000-0001-7527-3300

RICARDO V. PORTILHO

https://orcid.org/0000-0003-0204-0164

\section{RENATA MACULAN ${ }^{2}$}

https://orcid.org/0000-0002-5723-2510

\section{JOSÉ F. DE SOUZA JÚNIOR ${ }^{3}$}

https://orcid.org/0000-0002-5484-3084

\section{CAMILLA M. SILVA ${ }^{4}$}

https://orcid.org/0000-0001-5259-9316

PAULA G. RODRIGUES 4

https://orcid.org/0000-0003-1140-8899

\section{MARCELO S. EL AZZI}

https://orcid.org/0000-0002-2589-0965

\section{JOSÉ C. DE SOUZA 5}

https://orcid.org/0000-0002-2870-1189

${ }^{1}$ Universidade Federal de Lavras, Departamento de Medicina Veterinária, Av. Doutor Sylvio Menicucci, 1001, Campus Históricos, 37200-000 Lavras, MG, Brazil

${ }^{2}$ Instituto Federal do Sul de Minas, Rodovia Machado Paraguaçu, s/n, Km 3, Santo Antonio, Campus Machado, 37750-000 Machado, MG, Brazil

${ }^{3}$ Universidade José do Rosário Vellano, Departamento de Medicina Veterinária, Avenida Joao Júlio de Faria, 304, Nova Era, 37170-000 Boa Esperança, MG, Brazil ${ }^{4}$ Universidade Federal de Sergipe, Departamento de Zootecnia, Av. Marechal Rondon s/n, Rosa Elze, 49100-000 São Cristóvão, SE, Brazil

${ }^{5}$ Universidade Federal de Lavras, Departamento de Zootecnia, Av. Sul UFLA, s/n, Campus UFLA, 37200-000 Lavras, MG, Brazil

Correspondence to: Camilla Mendonça Silva

E-mail:camillamsazoo@gmail.com

\section{Author contributions}

Jesús Alfonso Sanchez Viafara, Ricardo Vilhena Portilho, Renata Maculan, José F. Souza Júnior performed data collection and investigation; Jesús Alfonso Sanchez Viafara writing - original draft; Paula Gomes Rodrigues, Marcelo Siqueira El Azzi supervised the findings of this work; José Camisão de Souza performed statistical analysis and language review; Camilla Mendonça Silva and Paula Gomes Rodrigues writing - review and editing of paper. All authors discussed the results, wrote the manuscript and contributed to the final manuscript.

\section{(c) BY}

